\title{
Pengaruh Kualitas Produk Smartphone Terhadap Keputusan Pembelian di Masa Pandemic Covid19
}

\author{
Hadita ${ }^{1}$, Wirawan Widjanarko ${ }^{1,}{ }^{*}$, Hafizah $^{2}$ \\ ${ }^{1}$ Fakultas Ekonomi dan Blsnis; Universitas Bhayangkara Jakarta Raya; Jl. Raya \\ Perjuangan, Marga Mulya, Bekasi Utara, Jawa Barat 17121. Telp: 021-88955882, 889955883; \\ e-mail: hadita.universitas@gmail.com; e-mail:wwidjanarko2@gmail.com \\ ${ }^{2}$ Fakultas Ilmu Komputer; Universitas Bhayangkara Jakarta Raya Jl. Raya Perjuangan, \\ Marga Mulya, Bekasi Utara, Jawa Barat 17121. Telp: 021-88955882, 889955883; e-mail: \\ hafizah@ubharajaya.ac.id \\ * Korespondensi: e-mail: wwidjanarko2@gmail.com
}

\begin{abstract}
The purpose of this study was to determine the effect of smartphone product quality on purchasing decisions during the Covid 19 pandemic. This study is a quantitative study using a questionnaire method. The population used in this study is the people in South Bekasi. The sampling technique used in this study was incidental sampling. In this research the dependent variable (dependent) Purchase Decision (Y), while the independent variable (independent) is Product Quality (X1). For the results of the validity test used on product quality and purchase decisions are valid, while the results of the reliability test in this study show that they are reliable. The result of this research is that the quality of Xiaomi Smartphone products has a positive and significant effect on purchasing decisions during the Covid 19 pandemic.
\end{abstract}

Keywords: Product Quality, Purchase Decision, and Smartphone

\begin{abstract}
Abstrak
Tujuan dari penelitian ini adalah untuk mengetahui pengaruh kualitas produk Smartphone terhadap keputusan pembelian di masa pandemic Covid 19. Penelitian ini merupakan penelitian kuantitatif dengan menggunakan metode kuesioner. Populasi yang digunakan dalam penelitian ini adalah masyarakat yang ada di Bekasi Selatan. Teknik sampling yang digunakan pada penelitian ini adalah sampling insidential. Dalam peneletian ini variabel terikat (dependen) Keputusan Pembelian (Y), sedangkan variabel bebas (independen) adalah Kualitas Produk (X1). Untuk hasil uji validitas yang digunakan pada kualitas produk dan keputusan pembelian adalah valid, sedangkan hasil uji realibitas pada penelitian ini menunjukkan reliable. Hasil dari penelitian ini adalah kualitas produk Smartphone Xiaomi berpengaruh secara positif dan signifikan terhadap keputusan pembelian di masa pandemic Covid 19.
\end{abstract}

Kata Kunci: Kualitas Produk, Keputusan Pembelian, dan Smartphone

\section{Pendahuluan}

Di era globalisasi saat ini kompetisi dalam bidang bisnis sangat bersaing.

Persaingan antar usaha mengharuskan perusahaan memiliki strategi untuk mengupayakan konsumen menggunakan produk yang dijualnya. Semakin banyak konsumen yang loyal akan menguntungkan pihak perusahaan. Di masa pandemic covid 19 semua aktivitas 
dituntut untuk dilakukan secara online. Oleh sebab itu usaha yang berkembang pesat saat ini adalah dunia teknologi dan komunikasi seperti alat komunikasi Smartphone. Smartphone atau telepon pintar merupakan alat komunikasi yang sangat dikenal di seluruh penjuru dunia mulai dari perkotaan sampai pedesaan. Alat ini tidak lagi dianggap alat mewah yang hanya segelintir orang saja yang mengetahuinya akan tetapi sudah dianggap sebagai kebutuhan pokok semua orang mulai dari anak-anak hingga orang dewasa. Sekarang ini hampir semua lapisan masyarakat menggunakan smartphone. Hal ini membuat persaingan penjualan smartphone semakin ketat. Hal ini terbukti berdasarkan riset IDC 2020 terdapat top 5 brand di Indonesia yaitu Vivo, Oppo, Samsung, Xiomi, dan Realme.

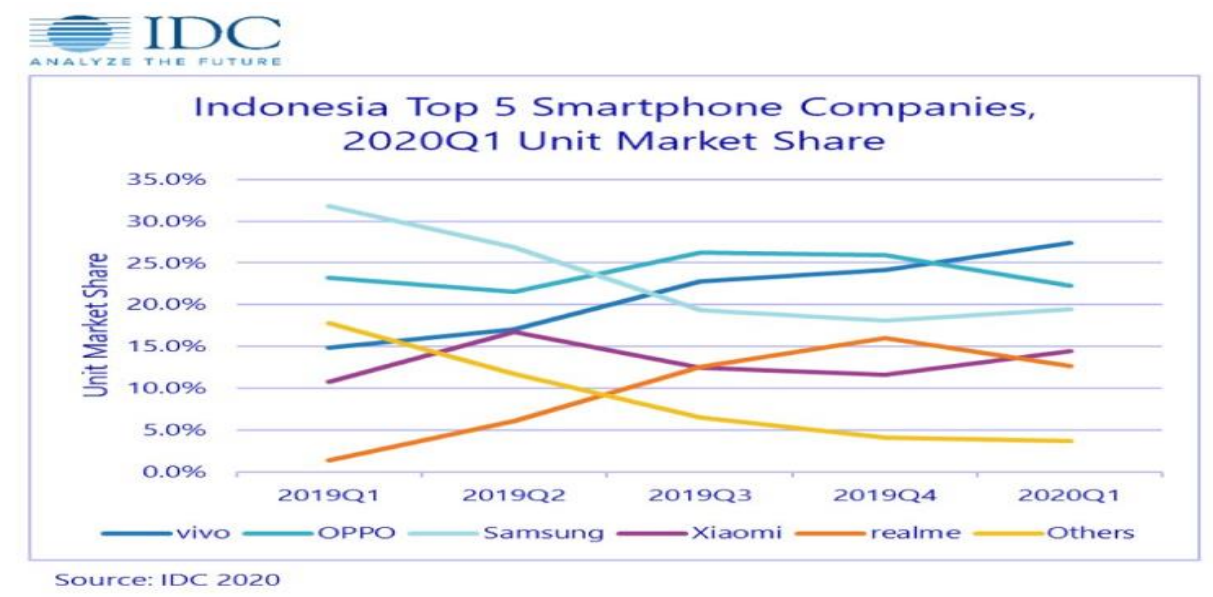

Sumber: Hasil Penelitian (2020)

Gambar 1. Indonesia Top 5 Smartphone Companies 2020

Terlihat dari gambar 1 bahwa keberadaan xiaomi masih berada jauh posisinya dibandingkan dengan Vivo, Oppo, dan Samsung. Namun demikian perkembangan Xiaomi sebagai produsen smartphone asal China keberadaannya mampu bersaing diantara vivo, oppo, realme, bahkan Samsung, dan saat ini smartphone xiaomi menjadi pilihan yang tepat bagi masyarakat menengah ke bawah karena dengan harga murah dan kualitas bagus tak kalah dengan Vivo, Oppo dan Samsung mereka dapat memiliki smartphone yang dapat menunjang aktivitas sehari-hari dimasa pandemic covid 19 saat ini.

Kemajuan Smartphone xiaomi terus berkembang melalui inovasi dalam kualitas produk. Kualitas produk merupakan kemampuan produk di dalam menjalankan fungsinya dan kualitas produk dapat diukur melalui pendapat konsumen tentang kualitas itu sendiri, sehingga selera pribadi sangat mempengaruhi. Kualitas itu sendiri sering dianggap sebagai ukuran relatif kebaikan suatu produk atau jasa. (Kresnamurti, Agung R.P, Putri, 2012). Konsumen senantiasa melakukan penilaian terhadap kinerja suatu produk, hal ini dapat dilihat dari kemampuan produk menciptakan kualitas produk dengan segala spesifikasinya sehingga dapat menarik konsumen untuk memutuskan membeli produk tersebut. Dalam penelitian ini akan digunakan tiga indikator (Santoso, 2016): Kemudahan penggunaan.yaitu mudah dipelajari, mudah dipahami, simple dan mudah pengoperasiannya., Fitur produk yaitu karakteristik produk yang di rancang untuk menyempurnakan fungsi produk atau menambah ketertarikan konsumen 
terhadap produk, dan daya tahan produk ketika digunakan. Selain itu, Menurut Sanjiwani \& Suasana (2019) Keputusan pembelian adalah seleksi terhadap dua pilihan alternatif atau lebih konsumen pada pembelian. Adapun indikator dalam keputusan pembelian adalah: kebutuhan dan keinginan akan suatu produk, keinginan mencoba, kemantapan akan kualitas suatu produk, dan keputusan pembelian ulang.

Di masa pandemic Covid 19 smartphone Xiaomi justru semakin meningkatkan kualitas produknya ditengah-tengah persaingan produk smartphone yang semakin marak dengan harapan banyak masyarakat tetap memutuskan untuk membeli produk ini. Berdasarkan penjelasan diatas maka kemenarikan penelitian ini adalah bagaimana pengaruh kualitas produk Smartphone terhadap keputusan pembelian di masa pandemic Covid 19.

\section{Metode Penelitian}

Penelitian ini merupakan penelitian kuantitatif dengan menggunakan metode kuesioner. Metode kuantitatif sebagai metode ilmiah/scientific karena telah memenuhi kaidah-kaidah ilmiah yaitu konkrit/empiris, obyektif, terukur, rasional, dan sistematis (Sekaran \& Bougie, 2014). Populasi yang digunakan dalam penelitian ini adalah masyarakat yang ada di Bekasi Selatan. Teknik sampling yang digunakan pada penelitian ini adalah sampling insidential.

Kerangka teori merupakan sintesa hubungan antara variabel yang disusun dari berbagai teori yang dideskripsikan. Kerangka teori akan menghubungkan secara teoritis antara variabel-variabel penelitian yaitu variabel dependen dan variabel independen. Dalam peneletian ini variabel terikat (depnden) Keputusan Pembelian ( $Y$ ), sedangkan variabel bebas (independen) adalah Kualitas Produk (X1).

Maka hipotesis pada penelitian ini adalah Kualitas Produk $(X)$ berpengaruh terhadap keputusan pembelian (Y).

\section{Hasil dan Pembahasan}

\subsection{Hasil Analisa Data}

\subsubsection{Uji Validitas}

Menurut Sekaran \& Bougie, (2014) uji validitas digunakan untuk mengukur sah atau valid tidaknya suatu kuesioner. Suatu kuesioner dikatakan sah atau valid jika pertanyaan pada kuesioner itu. Uji signifikansi dilakukan dengan membandingkan nilai $r$ hitung (nilai Corrected Item-Total Correction pada output Cronbach Alpha) dengan nilai $r$ table.

Tabel 1. Hasil uji Validitas Variabel Kualitas Produk

\begin{tabular}{llll}
\hline Korelasi & Sig R Hitung & Sig R Tabel & Kesimpulan \\
\hline Kualitas Produk - 1 & 0,00 & 0,050 & Valid \\
\hline Kualitas Produk - 2 & 0,00 & 0,050 & Valid \\
\hline Kualitas Produk - 3 & 0,00 & 0,050 & Valid
\end{tabular}




\begin{tabular}{llll}
\hline Korelasi & Sig R Hitung & Sig R Tabel & Kesimpulan \\
\hline Kualitas Produk -4 & 0,00 & 0,050 & Valid \\
\hline
\end{tabular}

Sumber: Hasil Pengolahan Data (2020)

Berdasarkan tabel 1 dinyatakan bahwa hasil dari uji validitas masing- masing pertanyaan dari variabel kualitas produk memiliki nilai sig $R$ hitung yang lebih kecil dari sig $R$ table $<0,050$ sehingga dapat disimpulkan bahwa lima butir pertanyaan yang ada pada variabel kualitas produk adalah Valid.

Tabel 2. Hasil Uji Validitas Variabel Keputusan Pembelian

\begin{tabular}{lclc} 
Korelasi & Sig R Hitung & Sig R Tabel & Kesimpulan \\
Keputusan Pembelian - & 0,00 & 0,050 & Valid \\
1 & & & Valid \\
$\begin{array}{l}\text { Keputusan Pembelian - } \\
2\end{array}$ & 0,00 & 0,050 & Valid \\
$\begin{array}{l}\text { Keputusan Pembelian - } \\
3\end{array}$ & 0,00 & 0,050 & Valid \\
$\begin{array}{l}\text { Keputusan Pembelian - } \\
4\end{array}$ & 0,00 & 0,050 & Valid \\
\hline $\begin{array}{l}\text { Keputusan Pembelian - } \\
5\end{array}$ & 0,00 & 0,050 &
\end{tabular}

Berdasarkan tabel 2 dinyatakan bahwa hasil dari uji validitas masing-masing pertanyaan dari variabel keputusan pembelian memiliki nilai sig $\mathrm{R}$ hitung yang lebih kecil dari sig $\mathrm{R}$ tabel $<$ 0,050 sehingga dapat disimpulkan bahwa lima butir pertanyaan yang ada pada variabel keputusan pembelian adalah Valid.

\subsubsection{Uji Reliabilitas}

Uji Reliabilitas dilakukan terhadap item pertanyaan yang dinyatakan valid, uji ini digunakan untuk mengukur kehandalan suatu kuesioner yang merupakan indikator dari variable tersebut. Uji reliabilitas dapat dilihat pada nilai dan uji reliabilitas dapat dilakukan bersama-sama terhadap seluruh butir pertanyaan. Untuk menentukan apakah instrumen reliabel atau tidak menggunakan batas 0,6 .

Tabel 3. Hasil Uji Reliabilitas

\begin{tabular}{llll}
\hline No Variabel & Alpha Cronbach & Kriteria & Kesimpulan \\
\hline 1. Kualitas Produk & 0,704 & 0,600 & Reliabel \\
\hline 2. Keputusan Pembelian & 0,699 & 0,600 & Reliabel \\
\hline
\end{tabular}


Pada tabel 4 hasil uji reliabilitas di atas diketahui bahwa nilai alpha Cronbach dari variabel harga 0,821, variabel kualitas produk 0,704 dan variabel keputusan pembelian 0,699. Dengan demikian dapat disimpulkan dari hasil uji ini Reliabel karena memiliki nilai alpha Cronbach $>0,600$.

\subsubsection{Analisis Regresi Sederhana}

Pada analisis regresi ini dilakukan untuk mengetahui derajat keeratan antara variabel kualitas produk smartphone Xiaomi terhadap variabel keputusan pembelian. Maka didapat hsil sebagai berikut:

Tabel 4. Hasil Analisis Regresi Sederhana Coefficients ${ }^{a}$

\begin{tabular}{|c|c|c|c|c|c|}
\hline \multirow[b]{2}{*}{ Model } & \multicolumn{2}{|c|}{$\begin{array}{c}\text { Unstandardized } \\
\text { Coefficients }\end{array}$} & \multirow{2}{*}{$\begin{array}{c}\text { Standardized } \\
\text { Coefficients } \\
\text { Beta }\end{array}$} & \multirow[b]{2}{*}{$t$} & \multirow[b]{2}{*}{ Sig. } \\
\hline & B & Std. Error & & & \\
\hline 1 (Constant) & 4.405 & .830 & & 5.308 & .000 \\
\hline Kualitas & .646 & .049 & .573 & 13.144 & .000 \\
\hline Produk & & & & & \\
\hline
\end{tabular}

a. Dependent Variabel: Keputusan Pembelian

Sumber: Hasil Pengolahan Data (2020)

Berdasarkan hasil analisis regresi sederhana, maka persamaa regresi yang dibentuk adalah: $Y=4,405+0,646 \mathrm{X}+\mathrm{e}$. Persamaan regresi sederhana tersebut menggambarkan bahwa:

1. Nilai konstanta sebesar 4,205 menyatakan bahwa besarnya nilai variabel $Y$ jika variabel bebasnya dianggap nol artinya tanpa dipengaruhi kualitas produk smartphone Xiaomi maka besarnya keputusan pembeliaankonsumen adalah tetap sebesar 4,205.

2. Koefisien regresi kualitas produk sebesar 0,646 menyatakan bahwa setiap terjadi penambahan kualitas produk sebesar 1 satuan, sedangkan variabel lain adalah tetap, maka hal tersebut akan mempengaruhi keputusan pembelian konsumen produk smartphone Xiaomi sebesar 0,646. Koefisien bernilai positif artinya terjadi hubungan positif antara kualitas produk smartphone xiaomi dengan keputusan pembeliaan.

\subsubsection{Analisis Korelasi}

Berikut adalah tabel analisis korelasi pada kualitas produk Smartphone Xiaomi terhadap keputusan pembelian: 
Tabel 5. Hasil Uji Determinasi $\left(R^{2}\right)$ Model Summary ${ }^{b}$

\begin{tabular}{|c|c|c|c|c|}
\hline Model & $\mathrm{R}$ & R Square & $\begin{array}{l}\text { Adjusted R } \\
\text { Square }\end{array}$ & $\begin{array}{l}\text { Std. Error of } \\
\text { the Estimate }\end{array}$ \\
\hline 1 & $.729^{a}$ & .531 & .529 & 1.679 \\
\hline
\end{tabular}

a. Predictors: (Constant) Kualitas Produk

Sumber: Hasil Pengolahan Data (2020)

Dari perhitungan pengolahan data maka didapat nilai korelasi variabel kualitas produk (R) sebesar 0,729 yang terdapat pada tabel 5 diatas. Dari penafsiran terdapat koefiesien korelasi tersebut kualitas produk smartphone Xiaomi memiliki hubungan yang sangat kuat terhadap keputusan pembelian.

\subsubsection{Koefisien Determinasi}

Pada hasil tabel 5 juga memperlihatkan nilai koefisien determinasi (R Square) yang digunakan untuk mengetahui persentase pengaruh variabel independen $(X)$ terhadap variabel dependen $(Y)$. Nilai $R$ Square sebesar 0,531 Menunjukkan bahwa keputusan pembelian konsumen dipengaruhi oleh kualitas produk smartphone Xiaomi sebesar 53,1\% Sedangkan sisanya sebesar $46,9 \%$ dipengaruhi oleh faktor-faktor lain yang tidak diteliti.

\subsection{Uji Hipotesis}

\subsubsection{Uji t}

Uji t dilakukan untuk mengetahui hubungan variabel bebas Kualitas Produk terhadap variabel terkait Keputusan Pembelian secara parsial.

Jika sig. $<0,05$, maka Ho ditolak, Ha diterima Jika sig. > 0,05, maka Ho diterima, Ha ditolak.

Tabel 6. Hasil Uji t (Parsial)

\begin{tabular}{|c|c|c|c|c|}
\hline \multirow[b]{2}{*}{ Model } & \multirow[b]{2}{*}{$\mathrm{t}$} & \multirow[b]{2}{*}{ Sig } & \multicolumn{2}{|c|}{ Collinearity Statistics } \\
\hline & & & Tolarance & VIF \\
\hline 1 (Constant) & 5.308 & .000 & & \\
\hline Kualitas Produk & 13.144 & .000 & .711 & 1.407 \\
\hline
\end{tabular}

Sumber: Hasil Pengolahan Data (2020)

Hasil dari tabel 6 diatas jika dilihat dari nilai sig. untuk variabel Kualitas Produk diperoleh dengan nilai sig. 0,00 0,05 atau nilai sig. lebih kecil dari 0,05 maka dari itu Ho ditolak dan Ha diterima yang berarti secara parsial variabel Kualitas Produk berpengaruh signifikan terhadap Keputusan Pembelian. 


\subsection{Pembahasan}

Pengaruh Kualitas Produk berpengaruh terhadap Keputusan Pembelian Berdasarkan hasil analisis data diperoleh hasil perhitungan uji t (Parsial) yang menunjukan nilai sig. 0,000< 0,05 atau nilai signifikan lebih kecil dari 0,05 . Oleh sebab itu $\mathrm{H}_{\mathrm{o}}$ ditolak atau $\mathrm{Ha}_{\mathrm{a}}$ diterima yang berarti bahwa secara parsial variabel Kualitas Produk berpengaruh signifikan terhadap Keputusan Pembelian. Sehingga Kualitas Produk dari Smartphone Xiaomi diterima oleh masyarakat. Penelitian ini didukung oleh peneliti sebelumnya Indah Siti Mahmudah, (2014); Riyono dan Gigih Erlik Budiharja, (2016); Wicaksono, (2016); Sunarto, (2015). Meskipun terdapat beberapa perbedaan dalam hal penelitian, dalam hal ini peneliti yang satu dengan peneliti yang lain, namun dalam hal analisis memberikan hasil yang sama pada pembuktiaan dimana kualitas produk memberikan pengaruh dalam keputusan pembeliaan produk apapun itu. Berdasarkan hasil penelitian ini dapat disimpulkan bahwa produk Smartphone Xiaomi mampu memberikan hasil atau kinerja yang sesuai dengan harapan pelanggan. Hal ini sesuai dengan teori yang dikemukkan oleh Kotler, (2016) bahwa kualitas produk merupakan kemampuan suatu barang dalam memberikan hasil atau kinerja sehingga dapat memenuhi segala yang dibutuhkan pelanggan.

\section{Kesimpulan}

Berdasarkan hasil dari penelitian yang dilakukan melalui uji analisis regresi sederhana dan uji hipotesis secara parsial bahwa kualitas produk berpengaruh signifikan terhadap keputusan pembelian. Hal ini menyatakan bahwa kualitas produk sangat berperan penting untuk meningkatkan daya tarik terhadap keputusan pembelian pelanggan smartphone Xioami di Bekasi Selatan. Perusahaan smartphone Xioami juga perlu berinovasi dari segi kualitas produknya dengan meningkatkan kualitas fitur-fitur yang semakin canggih dan mudah dalam pemakaiannya sehingga dapat menjawab segala kebutuhan pelanggan dari level manapun, dengan mampu bersaing dengan kompetitor dan dapat mempertahankan pelanggan yang sudah ada.

\section{Daftar Pustaka}

Indah Siti Mahmudah, M. T. (2014). Pengaruh Kualitas Produk, Citra Merek, Dan Harga Terhadap Keputusan Pembelian Pond's Flawless White. JURNAL BISNIS DAN MANAJEMEN, 6(2), 98-105.

Kotler, P. and K. L. K. (2016). Marketing Management. 15th Edition: New Jersey: Pearson Education, Inc.

Kresnamurti, Agung R.P, Putri, A. (2012). Pengaruh Kualitas Produk Dan Citra Merek Terhadap Loyalitas Konsumen Pada Produk Oli Federal Di Wilayah Jakarta Timur (Studi Kasus Pada Bengkel Resmi Ahass 2657 Dewi Sartika). Econo Sains, X, 1-14. 
Riyono dan Gigih Erlik Budiharja. (2016). Pengaruh Kualitas Produk, Harga, Promosi dan Brand Image terhadap Keputusan Pembelian Produk Aqua di Kota Pati. Jurnal STIE Semarang, 8(2). Retrieved from https://media.neliti.com/media/publications/133954-ID-pengaruhkualitas-produk-harga-promosi-d.pdf

Sanjiwani, N. M. D., \& Suasana, I. G. A. K. G. (2019). Peran Brand Image Dalam Memediasi Pengaruh Kualitas Produk Terhadap Keputusan Pembelian. E-Jurnal Manajemen Universitas Udayana, 8(11). Retrieved from https://doi.org/10.24843/ejmunud.2019.v08.i11.p17

Santoso, A. (2016). Pengaruh Kualitas Produk Dan Ekuitas Merek Terhadap Keputusan Pembelian. Ekuilibrium: Jurnal IImiah Bidang IImu Ekonomi, 11(1), 43. Retrieved from https://doi.org/10.24269/Ekuilibrium.V11i1.112

Sekaran, U., \& Bougie, R. (2014). Research Method For Business. In Library of Congress. https://doi.org/10.1007/978-94-007-0753-5_102084

Sunarto. (2015). Pengaruh Kualitas Produk terhadap Keputusan Pembelian pada Toko Kerajinan Kulit kartika Magetan. Jurnal Equilibrium, 3(2).

Wicaksono, B. R. (2016). Pengaruh Kualitas Produk terhadap Keputusan Pembelian Layanan Internet yang Dimediasi oleh Minat Beli (Studi Kasus pada Mahasiswa Pengguna Provider Tri di Fakultas Ekonomi Universitas Yogyakarta). Retrieved from http://eprints.uny.ac.id/42580/1/BagasRifkiWicaksono_11408144023.pdf 